\title{
Hubungan Mekanisme Koping dengan Kualitas Hidup Pasien Gagal Ginjal Kronik yang Menjalani Hemodialisis di Rumah Sakit Santa Elisabeth Medan
}

\author{
Meiling Siahaan ${ }^{1}$, Rosminta Girsang ${ }^{2}$, Ade Pryta Simaremare ${ }^{3}$ \\ ${ }^{1}$ Mahasiswa, Fakultas Kedokteran Universitas HKBP Nommensen \\ ${ }^{2}$ Departemen IImu Kedokteran Jiwa Fakultas Kedokteran Universitas HKBP Nommensen \\ ${ }^{3}$ Departemen Mikrobiologi Fakultas Kedokteran Universitas HKBP Nommensen \\ Korespondensi: Meiling Siahaan, Email: hildafonsa@gmail.com
}

\begin{abstract}
Background: Chronic kidney failure is a state of progressive, irreversible destruction of kidney structure that requires permanent kidney replacement therapy. Global prevalence is $11.7 \%-15.1 \%$. Chronic disease conditions and prolonged treatment can affect the patient's mental health and quality of life. The process by which a person attains physical and mental readiness in dealing with stressful situations is called coping. Quality of life is an individual's perception of their position in life. The aim of this study was to determine the relationship between coping mechanisms and quality of life in patients with chronic renal failure undergoing hemodialysis.
\end{abstract}

Methods: This research was analytical correlative with cross sectional research design. Sampling with consecutive sampling technique and obtained as many as 35 respondents. The criteria for patients in this study were patients diagnosed with chronic renal failure and undergoing hemodialysis with an age limit of 18 - 65 years, compos mentis awareness status and willingness to become respondents. The study was conducted in November 2019- January 2020. Patient data were obtained through medical records and questionnaires kidney disease quality of life short form (KDQOL-SF) and a brief cope scale.

Results: The results of statistical tests obtained $p$ value $=0.007$ and $r=0.413(p<0.05 ; r>0.05)$. These results indicate that there is a relationship between coping mechanisms and quality of life in patients with chronic renal failure undergoing hemodialysis. More male respondents than women with 56-65 years age group, the highest education status is college; working as a civil servant, long undergoing HD 1-12 months. Based on statistical analysis it is known that the coping mechanism of poor respondents (57.1\%), poor quality of life (54.3\%).

Conclusions: There was significant relationship between coping mechanisms with the quality of life of patients with chronic renal failure undergoing hemodialysis with moderate correlation strength and positive direction.

Keywords: Coping mechanism, quality of life, chronic kidney failure

\begin{abstract}
Abstrak
Latar belakang: Penyakit gagal ginjal kronik merupakan keadaan destruksi struktur ginjal yang progresif, ireversibel dan membutuhkan terapi pengganti ginjal yang menetap. Prevalensi secara global 11,7\%-15,1\%. Kondisi penyakit yang kronik dan pengobatan yang lama dapat memengaruhi kejiwaan dan kualitas hidup pasien. Proses yang digunakan seseorang untuk memperoleh kesiapan fisik dan mental dalam menghadapi situasi yang menimbulkan stres disebut koping. Kualitas hidup adalah persepsi individu tentang posisi mereka dalam kehidupan. Tujuan penelitian ini adalah untuk mengetahui hubungan mekanisme koping dengan kualitas hidup pasien gagal ginjal kronik yang menjalani hemodialisis.
\end{abstract}


Metode: Penelitian ini bersifat analitik korelatif dengan desain penelitian cross sectional. Pengambilan Sampel dengan teknik consecutive sampling dan diperoleh sebanyak 35 responden. Kriteria pasien dalam penelitian ini yakni pasien yang terdiagnosis gagal ginjal kronik dan menjalani hemodialisis dengan batasan usia 18 tahun - 65 tahun, status kesadaran compos mentis dan bersedia menjadi responden. Penelitian dilakukan pada bulan November 2019- Januari 2020. Data pasien diperoleh melalui rekam medis dan kuesioner kidney disease quality of life short form (KDQOL-SF) dan brief cope scale.

Hasil: Hasil uji statistik diperoleh nilai $p=0,007$ dan $r=0,413(p<0,05 ; r>0,05)$. Hasil ini menunjukkan bahwa terdapat hubungan antara mekanisme koping dengan kualitas hidup pasien gagal ginjal kronik yang menjalani hemodialisis. Responden laki-laki lebih banyak dibanding perempuan dengan kelompok usia 56-65 tahun, status pendidikan terbanyak yakni perguruan tinggi; bekerja sebagai PNS, lama menjalani HD 1-12 bulan. Berdasarkan analisis statistik diketahui bahwa Mekanisme koping responden buruk $(57,1 \%)$, kualitas hidup buruk $(54,3 \%)$.

Kesimpulan: Ada hubungan yang bermakna antara mekanisme koping dengan kualitas hidup pasien gagal ginjal kronik yang menjalani hemodialisis dengan kekuatan korelasi sedang dan arah positif.

Kata Kunci: mekanisme koping, kualitas hidup, gagal ginjal kronik

\section{Pendahuluan}

Penyakit gagal ginjal kronik (GGK) merupakan penurunan fungsi ginjal secara progresif dalam beberapa bulan atau beberapa tahun. Penyakit ginjal kronik terjadi setelah berbagai macam penyakit yang merusak nefron ginjal. Secara perlahan-lahan akan terjadi penurunan fungsi ginjal yang ireversibel. ${ }^{1}$ Penyakit gagal ginjal kronik memilki prevalensi global yang tinggi dengan estimasi 11,7\%-15,1\%. ${ }^{2}$ Riset kesehatan dasar (Riskesdas) tahun 2018 menunjukkan prevalensi penyakit tersebut mengalami kenaikan dari $2 \%$ pada tahun 2013 menjadi $3,8 \%$ pada tahun $2018 .^{3}$ Oleh karena itu dibutuhkan tindakan yang dapat membantu mengurangi beban kerja ginjal salah satunya dengan melakukan terapi hemodialisis. Menurut data Indonesia renal registry tahun 2017 terdaftar sekitar 77.892 pasien aktif yang menjalani hemodialisis (HD) dan sekitar 30.831 pasien baru yang menjalani HD. ${ }^{4}$ Pengobatan pasien gagal ginjal kronik membutuhkan waktu yang lama dan biaya yang besar sehingga butuh kesabaran pasien dan dukungan keluarga dalam menjalani terapi. Hal ini secara perlahan akan memengaruhi kejiwaan pasien dan kualitas hidup pasien.

Setiap orang mempunyai respon yang berbeda dalam menanggapi masalah atau perubahan dalam dirinya. Upaya yang digunakan oleh seseorang dalam menangani situasi yang menimbulkan stres disebut dengan koping. Koping yang digunakan seseorang dapat memberi dampak positif atau negatif pada kualitas hidup. Koping yang efektif akan memberi dampak yang baik dan sebaliknya koping yang kurang efektif akan memberi dampak yang kurang baik. Penelitian yang dilakukan oleh Nowak pada pasien gagal ginjal yang menjalani hemodialisis sebagian besar menggunakan strategi represif, strategi penolakan / penghindaran untuk mencapai hasil yang memuaskan dalam persepsi kualitas hidup. ${ }^{5}$ Penelitian yang dilakukan Barberis dan kawan-kawan menegaskan bahwa strategi koping yang berfokus pada masalah akan memberikan kualitas hidup yang lebih baik, sedangkan strategi koping yang berpusat pada emosi akan memberikan dampak yang kurang baik pada kualitas hidup. ${ }^{6}$

Kualitas hidup adalah persepsi individu tentang posisi mereka dalam kehidupan dalam konteks budaya dalam sistem nilai dimana mereka tinggal dan dalam hubungan mereka dengan tujuan, harapan, standar hidup dan masalah. Beberapa hal yang dapat memengaruhi kualitas hidup diantaranya sosio-ekonomi-kultural setempat, kondisi kesehatan fisik/psikis (mental emosional). Hasil penelitian yang dilakukan Mulia dan kawan-kawan menunjukkan kualitas hidup pasien gagal ginjal kronik untuk domain fisik dan psikologis berada pada tahap sedang, domain lingkungan dan sosial berada pada kategori kualitas hidup baik.7

Berdasarkan uraian di atas maka peneliti tertarik melakukan penelitian tentang hubungan mekanisme koping dengan kualitas hidup pasien gagal ginjal kronik yang menjalani hemodialisis.

Tujuan penelitian ini adalah Untuk mengetahui apakah terdapat hubungan antara mekanisme koping dengan kualitas hidup pasien gagal ginjal kronik yang menjalani hemodialisis.

\section{Metode}

Penelitian ini merupakan penelitian analitik korelatif dengan desain penelitian Cross sectional, yang dilakukan di unit hemodialisis rumah sakit Santa Elisabeth Medan sejak bulan November 2019 Mei 2020. Alasan memilih rumah sakit Santa Elisabeth sebagai tempat penelitian selain dekat dengan tempat tinggal peneliti juga karena belum pernah dilakukan penelitian tentang hubungan mekanisme koping dengan kualitas hidup pasien pasien gagal ginjal kronik yang menjalani hemodilisis di rumah sakit tersebut. Cara pengambilan sampel menggunakan teknik consecutive sampling. Menggunakan rumus besar sampel untuk penelitian korelatif dengan tingkat kepercayaan $95 \%$ dan power penelitian $90 \%$ korelasi minimal dianggap bermakna sebesar 0,05 . Responden pada penilitian ini ialah pasien dengan diagnosis gagal ginjal kronik yang menjalani $H D$, rentang usia 18 tahun -65 tahun yakni sebanyak 35 orang dan bersedia mengsisi informed consent dan kuesioner penelitian yang terdiri dari kuesioner kidney diseases quality of life short form (KDQOLS-SF) versi 1.3 dan kuesioner Brief Cope scale. Analisis univariat digunakan untuk menilai karakteristik demografi responden yakni jenis kelamin, usia, agama, suku, pekerjaan, pendidikan terakhir, lama menjalani hemodialisis dan distribusi masing-masing item dari kuesioner. Analisis bivariat dilakukan untuk melihat hubungan mekanisme koping dengan kualitas hidup pasien gagal ginjal kronik yang 
menjalani hemodialisis. Normalitas Data diuji dengan uji normalitas Saphiro wilk dan uji korelasi pearson. Korelasi dianggap bermakna apabila nilai $p<0,05$.

\section{Hasil}

Deskripsi karakteristik subjek penelitian dapat dilihat pada tabel 1. Berdasarkan data tabel.1 dapat diketahui responden laki-laki sebanyak 20 orang $(57,1 \%)$, perempuan 15 orang $(42,9 \%)$. Rentang usia 56-65 sebanyak 17 orang (48,6\%). Data tingkat pendidikan terdapat 14 orang $(40,0 \%)$ yang menyelesaikan perguruan tinggi dan 1 orang (2,9\%) tidak sekolah. Mayoritas pasien bekerja sebagai PNS sebanyak 13 orang $(37,1 \%)$. Berdasarkan data status perkawinan 32 orang $(91,4 \%)$ menikah.

Tabel 1. Karakteristik Subyek Penelitian

\begin{tabular}{lcc}
\hline Keterangan & $\mathbf{n}$ & \% \\
\hline Jenis Kelamin & & \\
Laki-laki & 20 & 57.1 \\
Perempuan & 15 & 42.9 \\
\hline Kelompok Usia & & \\
26-35 tahun & 1 & 2.9 \\
36-45 tahun & 6 & 17.1 \\
46-55 tahun & 11 & 31.4 \\
56-65 tahun & 17 & 48.6 \\
\hline Agama & & \\
Islam & 10 & 28.6 \\
Katolik & 10 & 28.6 \\
Kristen Protestan & 14 & 40.0 \\
Budha & 1 & 2.9 \\
\hline Pendidikan & & \\
Tidak Sekolah & 1 & 2.9 \\
SD & 5 & 14.3 \\
SMP/SLTP & 3 & 8.6 \\
SMA/SLTA & 12 & 34.3 \\
Perguruan Tinggi & 14 & 40.0 \\
\hline Pekerjaan & & \\
PNS & 13 & 37.1 \\
Pegawai Swasta & 2 & 5.7 \\
Pedagang & 9 & 25.7 \\
lbu Rumah Tangga & 4 & 11.4 \\
Petani & 5 & 14.3 \\
Tidak Bekerja & 2 & 5.7 \\
\hline Suku & & \\
Batak Toba & 19 & 54.3 \\
Batak Karo & 9 & 25.7 \\
Jawa & 4 & 11.4 \\
Nias & 1 & 2.9 \\
Melayu & 2.9 \\
Lainnya & 1 & 2.9 \\
\hline Lama HD (bulan) & & \\
1-12 bulan & 13 & 37.1 \\
13-24 bulan & 7 & 20.0 \\
25-36 bulan & 4 & 11.4 \\
37-48 bulan & 22.9 \\
49-60 bulan & 3 & 8.6 \\
\hline Total & 35 & 100 \\
\hline & & \\
& & \\
& & \\
\hline
\end{tabular}

Suku yang paling banyak menderita gagal ginjal kronik ialah suku Batak Toba sebanyak 19 orang (54,3\%). Agama yang dianut oleh responden Kristen Protestan sebanyak 14 orang $(40,0 \%)$.
Berdasarkan lama menjalani hemodialisis diperoleh sebanyak 13 orang $(37,1 \%)$ menjalani HD dengan rentang waktu 1-12 bulan. Berdasarkan tabel 2 dapat diketahui skor koping dan skor kualitas hidup pasien yang menjalani hemodialisis. Skor koping berada dalam kategori buruk yakni 20 orang $(57,1 \%)$. Nilai rata-rata total skor koping sebanyak 69,57 . Skor kualitas hidup buruk sebanyak 19 orang $(54,3 \%)$ dan 16 orang $(45,7 \%)$ memiliki kualitas hidup baik dengan rerata kualitas hidup sebesar 59,46 dan termasuk dalam kategori kualitas hidup buruk.

Tabel 2. Skor koping dan skor kualitas hidup pasien gagal ginjal kronik

\begin{tabular}{llccc}
\hline & Skor & N & $\%$ & Mean \\
\hline \multirow{2}{*}{ Koping } & Baik & 15 & 42.9 & \multirow{2}{*}{69.57} \\
& Buruk & 20 & 57.1 & \\
\hline \multirow{2}{*}{ Kualitas hidup } & Baik & 16 & 45.7 & \multirow{2}{*}{59.46} \\
& Buruk & 19 & 54.3 & \\
\hline
\end{tabular}

Data awal dalam penelitian ini tidak terdistribusi normal maka dilakukan transformasi data. Setelah data berdistribusi normal maka dilakukan uji korelasi menggunakan uji korelasi pearson. Uji analisis korelasi dapat dilihat pada tabel 3 . Berdasarkan tabel 3 dapat diketahui hasil uji korelasi pearson dengan n sebanyak 35 orang didapatkan nilai $r$ sebesar 0,413 dan nilai p sebesar 0.007 . $\mathrm{Hal}$ ini berarti terdapat korelasi yang signifikan antara koping dengan kualitas hidup pasien gagal ginjal kronik yang menjalani hemodialisis dan arah positif dengan kekuatan korelasi sedang.

Tabel 3. Hubungan Mekanisme Koping Dengan Kualitas Hidup Pasien Gagal Ginjal Kronik Yang Menjalani Hemodialisis

\begin{tabular}{ll}
\hline & Kualitas Hidup \\
\hline \multirow{3}{*}{ Koping } & $\mathrm{r}=0.413$ \\
& $\mathrm{p}=0.007$ \\
& $\mathrm{n}=35$
\end{tabular}

\section{Pembahasan}

Dalam penelitian ini karakteristik responden dinilai berdasarkan jenis kelamin, kelompok usia, pendidikan, pekerjaan dan lama menjalani hemodialisis. Responden paling banyak laki-laki $(56,71 \%)$ sedangkan perempuan $(42,9 \%)$. Hal ini sejalan dengan penelitian yang dilakukan oleh Winson yang menyatakan bahwa pasien gagal ginjal kronik yang menjalani hemodialisis paling banyak adalah laki-laki 19 orang $(67,9 \%) .8,4$ Berdasarkan data tersebut tampak bahwa ada perbedaan prevalensi penderita gagal ginjal kronik berdasarkan jenis kelamin, hal ini karena perempuan memiliki hormon estrogen yang menghambat pembentukan sitokin untuk menghambat osteoklas agar tidak berlebihan menyerap tulang, sehingga kadar kalsium seimbang. Kalsium memiliki peran dalam pencegahan penyerapan oksalat yang dapat membentuk batu ginjal. ${ }^{9}$

Kelompok usia terbanyak dalam penelitian ini usia 56-65 tahun sebanyak 17 orang (48,6\%). Hal ini sejalan dengan data Indonesian Renal registry yakni distribusi usia pasien HD paling banyak usia 45-64 tahun. ${ }^{4}$ Penelitian Widyastuti menunjukkan hasil yang sama yaitu sebanyak 42 orang (72\%).10 Berdasarkan data tersebut dapat diketahui bahwa semakin tua usia seseorang 
semakin rentan terkena penyakit ginjal kronik sebagai akibat adanya penurunan fungsi ginjal yakni sekitar $1 \mathrm{ml} /$ menit setiap tahun. ${ }^{1}$

Frekuensi tingkat pendidikan terbanyak dalam penelitian pada perguruan tinggi sebanyak (40,0\%). Penelitian yang dilakukan Tanor dan kawan-kawan menyatakan 77 responden $(38,1 \%)$ memiliki pendidikan perguruan tinggi. ${ }^{11} \mathrm{Hal}$ ini menunjukkan bahwa semakin tinggi tingkat pendidikan seseorang maka kesadaran akan pentingnya kesehatan dan pengobatan juga akan semakin tinggi. ${ }^{12}$

Status pekerjaan pada penelitian ini paling banyak merupakan pegawai negeri sipil 37,1\%. Hal ini sejalan dengan data Riskesdas bahwa pasien gagal ginjal kronik yang menjalani terapi hemodialisis paling banyak diderita oleh pasien dengan pekerjaan PNS. ${ }^{3}$ Biaya terapi hemodialisis tergolong cukup mahal dan menjadi beban tersendiri bagi pasien, namun hal ini dapat diatasi dengan mengurus kartu asuransi kesehatan. ${ }^{13}$

Lama hemodialisis merupakan waktu yang telah dilalui seorang pasien gagal ginjal kronik dalam menjalani terapi hemodialisis. Dalam penelitian ini sebanyak 13 orang $(37,1 \%)$ menjalani HD dalam rentang waktu 1-12 bulan. Sejalan dengan penelitian Syaiful yakni sebanyak 23 orang (39\%) menjalani HD pada rentang waktu $<12$ bulan. ${ }^{14} \mathrm{Hal}$ yang sama ditunjukkan oleh Wahyuni yakni sebanyak 17 orang (55\%) pasien yang menjalani HD $<12$ bulan. ${ }^{15}$ Pasien yang baru menjalani HD memiliki tingkat depresi yang bervariasi dari tidak ada depresi sampai depresi berat sedangkan pasien yang telah lama menjalani hemodialisis memiliki tingkat depresi yang ringan kemungkinan pasien sudah mencapai tahap penerimaan dan pasien telah mendapat pendidikan dari tenaga kesehatan tentang penyakitnya.

Berdasarkan hasil penelitian diketahui sebanyak $57,1 \%$ responden memiliki skor koping buruk dan 42,9\% memiliki skor koping baik. Mekanisme koping yang digunakan responden ialah mekanisme koping berfokus masalah dengan nilai mean 5,02 . Hasil penelitian ini sejalan dengan penelitian Albai yakni 45 orang menggunakan koping fokus masalah dan 37 orang mengunakan koping fokus emosi. ${ }^{16}$ Strategi terfokus masalah yakni suatu metode penanganan masalah dengan memfokuskan pada situasi yang terjadi sambil mencoba menemukan cara untuk mengubahnya. Kemampuan seseorang menerapkan strategi tersebut tergantug pada pengalaman dan kapasitasnya untuk mengendalikan diri. Dalam penelitian ini pasien dominan menggunakan subskala keagamaan. Pasien merasakan agama dapat membantu mengatasi masalah dengan beberapa alasan yakni: ada keyakinan menemukan makna dalam setiap peristiwa hidup, kepercayaan menghasilkan kesehatan yang lebih baik, menghadiri kegiatan keagamaan dapat mengurangi stress. Selain agama pasien juga patuh terhadap terapi yang diresepkan dokter, hal ini tampak dari angka penggunaan obat diluar resep dokter merupakan subskala yang paling sedikit digunakan oleh pasien yakni 2,06. Kepatuhan dalam penggunaan obat merupakan hal yang penting dalam meningkatkan keberhasilan terapi sehingga dapat meningkatkan kualitas hidup. ${ }^{17,18}$

Berdasarkan data yang diperoleh frekuensi kualitas hidup pasien gagal ginjal kronik yang menjalani hemodialisis sebanyak 19 orang
$(54,3 \%)$ memiliki kualitas hidup yang buruk. Penelitian yang dilakukan oleh Rahman dengan kuesioner yang berbeda namun nilai skor sama (0-100) diperoleh data bahwa pasien yang menjalani hemodialisis lebih dari enam bulan maupun kurang dari enam bulan memiliki kualitas hidup yang rendah. ${ }^{19}$ Kualitas hidup merupakan gambaran aspek kebahagiaan yang dialami seseorang dan bersifat subyektif. Kualitas hidup merupakan konsep yang mempresentasikan respon individu terhadap kemungkinan efek fisik, mental dan sosial dari suatu penyakit. 7 Semakin lama pasien mejalani HD maka pasien tersebut semakin patuh dan teratur melaksanakan HD karena pasien sudah dapat menerima kondisi penyakitnya karena sudah memperoleh edukasi dari perawat dan dokter akan manfaat HD secara teratur serta dukungan keluarga. ${ }^{15}$ Beberapa pasien masih sulit menerima kondisi sakit saat ini dan cenderung memiliki kualitas hidup yang buruk. Ini terbukti dari beberapa aspek yang memiliki nilai rendah seperti penderitaan karena sakit ginjal $(43,75)$, status pekerjaan $(20,00)$, peran fisik $(17,86)$, Pesepsi kesehatan $(58,07)$, kesejahteraan emosional $(30,05)$, peran emosional $(29,52)$ dan energi/kelelahan $(35,44)$.

Berdasarkan hasil analisis korelasi pearson terdapat hubungan yang signifikan secara statistik $p=0,007(p<0,05)$ dengan kekuatan korelasi sedang dan arah positif $r=0,413(r>0,05)$. Penelitian yang dilakukan oleh Aldi menunjukkan ada hubungan antara mekanisme koping dengan kualitas hidup pada pasien yang menjalani hemodialisis dengan korelasi hubungan yang lemah $(p=0,041 ; r=0,299)$. Pasien yang menjalani hemodialisis akan mengalami stres secara psikologis. Mereka yang awalnya bebas melakukan aktivitas, bebas mengkonsumsi makanan dan minuman, secara perlahan-lahan akan mengalami pembatasan cairan, makanan, aktivitas, bekerja akan terikat dengan tenaga kesehatan. Hal ini menyebabkan pasien tidak produktif dan berdampak pada penghasilan secara finansial..$^{20}$

Koping yang digunakan seseorang dalam memenuhi kebutuhannya bergantung pada bagaimana orang tersebut menangani situasi yang mengandung tekanan atau masalah. Hal ini termasuk melakukan perubahan terhadap situasi dan menghindar dari situasi yang dihadapi, dari kedua cara ini jika berhasil individu tersebut akan merasa aman dan puas, bila tidak berhasil individu tersebut merasa tidak aman dan tidak puas dan belajar untuk hidup dengan ketidaknyamanan. Oleh karena itu penting bagi seseorang untuk memiliki komitmen dan kemampuan menciptakan makna hidup dalam pengalaman yang buruk, untuk tetap menjaga adanya harapan untuk hidup dan kontrol diri, serta dukungan dari luar dirinya. ${ }^{21}$

Dalam penelitian ini tidak dapat dijelaskan secara spesifik mekanisme koping yang digunakan responden hanya berdasarkan nilai mean, oleh karena itu diharapkan agar peneliti selanjutnya menggunakan sampel yang lebih banyak dan kuesioner yang berbeda. Melakukan penelitian tentang efektifitas pendampingan secara fisik dan psikis tim kesehatan terhadap pasien yang menderita penyakit gagal ginjal kronis yang menjalani hemodialisis. Serta melakukan penelitian tentang hubungan mekanisme koping dengan lama menjalani hemodialisis pada pasien gagal ginjal kronik. 


\section{Kesimpulan}

Mekanisme koping dan kualitas hidup pasien gagal ginjal yang menjalani hemodialisis di Rumah Sakit Santa Elisabeth Medan tergolong buruk.

\section{Ucapan Terima Kasih}

Peneliti secara khusus mengucapkan terimakasih kepada Unit Hemodialisa Rumah sakit Santa Elisabeth Medan yang telah membantu dan mendukung saya dalam menyelesaikan penelitian ini.

\section{Daftar Pustaka}

1. Price S A. Patofisiologi. 6th ed. Hartanto H, Wulansari P, Susi N, Mahanani DA, editors. Jakarta: EGC; 2005.

2. Coresh J. Update on the Burden of CKD. J Am Soc Nephrol 28 [Internet]. 2017:4:1020-1022. [dikutip 15 juli 2019]. Tersedia pada https://jasn.asnjournals.org/content/28/4/1020

3. Balitbankes. Hasil utama Riskesdas 2018 [Internet]. Kementerian Kesehatan Republik Indonesia. 2018. [dikutip 2 September 2019]. Tersedia pada:https://www.kemkes.go.id/resources/download/info-terkini/hasilriskesdas-2018.pdf

4. Indonesian Renal Registry. 10th report of Indonesian renal registry. [Internet]. Pernefri. 2017 [dikutip 11 Agustus 2019]. Tersedia pada: https://www.indonesianrenalregistry.org/data/IRR 2017.pdf

5. Nowak Z, Wańkowicz, Zofia, Laudanski, Krzysztof. Denial defense mechanism in dialyzed patients. Med Sci Monit. 2015;21:1798-1804.

6. Barberis N, Cernaro V, Costa S, Montalto G, Lucisano S, Larcan R, et al. The relationship between coping, emotion regulation, and quality of life of patients on dialysis. Int J Psychiatry Med 2017;Vol. 52(2):111-123.

7. Mulia DS, Mulyani E, Pratomo GS, Chusna N. Kualitas hidup pasien gagal ginjal kronis yang menjalani hemodialisis di rsud dr. doris sylvanus palangka raya. Borneo J Pharm. 2018;1:19-21.

8. Jos W. Kualitas hidup pasien yang menjalani hemodialisis rutin di RSUD Tarakan, Kalimantan Utara, 2014. 2016;4 no 2:89.

9. Mayuda A, Chasani S, Saktini F. Hubungan antara lama hemodialisis dengan kualitas hidup pasien penyakit ginjal kronik (studi di rsup dr.kariadi semarang. Jurnal Kedokteran Diponegoro. 2017;6 no 2:167-174.
10. Widyastuti R, WR.Butar-Butar, Bebasari E. Korelasi lama menjalani hemodialisis dengan indeks massa tubuh pasien gagal ginjal kronik di RSUD Arifin achamad provinsi Riau pada bulan Mei tahun 2014. JOM FK. 2014;vol 1 no 2:3-4.

11. Tannor EK, Norman BR, Adusei KK, Sarfo FS, Davids MR, Bedu-Addo, et al. Quality of life among patients with moderate to advanced chronic kidney disease in Ghana - a single centre study. BMC Nephrol. 2019;1-8.

12. Firmansyah, Fadraersada J, Rusli R. Kajian kualitas hidup pasien yang menjalani hemodialisa di RSUD. A.W. Sjahranie. Mulawarman Pharm Conf. 2018;53.

13. Caninsti R. Kecemasan dan depresi pada pasien gagal ginjal kronis yang menjalani terapi hemodialisis. J Psikol Ulayat. 2013;Vol 1 no 2:207-22.

14. Syaiful $H Q$, Oenzil $F$, Afriant $R$. Hubungan umur dan lamanya hemodialisis dengan status gizi pada penderita penyakit ginjal kronik yang menjalani hemodialisis di RS. Dr. M. Djamil Padang. jurnal.fk.unand.ac.id. 2014;381385.

15. Wahyuni $P$, Miro $S$, Kurniawan E. Hubungan lama menjalani hemodialisis dengan kualitas hidup pasien penyakit ginjal kronik dengan diabetes melitus di RSUP Dr. M Djamil Padang. J Kesehat Andalas. 2018;481-482.

16. Albai A, Sima A, Papava I, Roman D, Andor B, Gafencu M. Assosiation between coping mechanisms and adherence to diabetes related self care activities: a cross sectional study. Patient Prefer Adherence. 2018;12351240.

17. Kusniawati. Hubungan kepatuhan menjalani hemodialisis dan dukungan keluarga dengan kualitas hidup pasien gagal ginjal kronik di ruang hemodialisa rumah sakit umum kabupaten tangerang. J Med Ed 2. 2018; Volume 5:225.

18. Karuniawati E, Supadmi W. kepatuhan penggunaan obat dan kualitas hidup pasien hemodialisa di rs PKU Muhammadiyah Yogyakarta periode Maret 2015. J Farm sains dan komunitas. 2016;vol 13 no:73-80.

19. Rahman MTSA, Kaunang TMD, Elim C. Hubungan antara lama menjalani hemodialisis dengan kualitas hidup pasien yang menjalani hemodialisis di unit hemodialisis RSUP. Prof. Dr. R. D. Kandou Manado. e-clinic. 2016;4:38-9.

20. Mollaoğlu M. Quality of life in patients undergoing hemodialysis [Internet]. Intech. 2013. [dikutip 6 Maret 2019]. Tersedia pada:https://scihub.tw/https://www.intechopen.com/books/hemodialysis/quality-of-life-inpatients-undergoing-hemodialysis

21. Elvira S D. Buku Ajar Psikiatri. 3rd ed. Jakarta: FKUI; 2017. p.44-47. 